\title{
PENGARUH METODE PEMBELAJARAN OUTDOOR STUDY DALAM BENTUK FIELD WORK PADA MATERI KEGIATAN EKONOMI TERHADAP HASIL BELAJAR IPS TERPADU SISWA SMP
}

\author{
Tri Utami Ermawati ${ }^{1}$, Risma Dwi Arisona ${ }^{2}$ \\ ${ }^{1}$ Institut Agama Islam Negeri Ponorogo, \\ ermaw0202@gmail.com \\ ${ }^{2}$ Institut Agama Islam Negeri Ponorogo \\ arisona@iainponorogo.ac.id
}

\begin{abstract}
ABSTRAK
Penelitian ini dilatarbelakangi oleh siswa yang berasumsi bahwa mata pelajaran IPS terpadu hanyalah bersifat hafalan, metode ceramah dan bahan ajar yang terbatas. Hal tersebut mengakibatkan hasil belajar menjadi rendah dan tidak maksimal. Perlakuan penelitian ini menggunakan metode outdoor study dalam bentuk field work (kelas eksperimen) dan pembelajaran metode tanya jawab, diskusi dan presentasi (kelas kontrol). Populasi penelitian adalah seluruh siswa kelas VII SMPN 1 Jenangan (183 siswa), sampelnya adalah VII C dan VII D yang berjumlah 62 siswa. Instrument tes hasil belajar berupa soal berjumlahkan 30 soal ( 25 soal pilihan ganda dan 5 soal esai) serta LKS saat melakukan observasi. Pengumpulan data dengan tes, observasi, dokumentasi. Data gain score dianalisis menggunakan Uji Independent Sample T-Test dengan program SPSS Versi 25. Hasil penelitian yaitu pelaksanaan metode pembelajaran outdoor study dalam bentuk field work pada materi kegiatan ekonomi terhadap hasil belajar IPS terpadu siswa SMP dan terdapat pengaruh signifikan metode outdoor study dalam bentuk field work pada materi kegiatan ekonomi terhadap hasil belajar IPS terpadu siswa SMP. Hal ini dapat dilihat dari nilai rata-rata gain score kelas eksperimen lebih tinggi (34.55) daripada kelas kontrol (21.29). Hasil analisis uji Independent Sample T-Test, diperoleh nilai p-level 0.000. Nilai p-level lebih kecil dari $0.05(\mathrm{p}<0.05)$.
\end{abstract}

Kata kunci: Outdoor study, field work, hasil belajar, IPS terpadu

\section{ABSTRACT}

This research was motivated by students who assumed that integrated social studies subjects were only memorization, lecture methods and limited teaching materials. This results in low and not optimal learning outcomes. The treatment of this research uses the outdoor study method in the form of field work (experimental class) and learning methods of question and answer, discussion and presentation (control class). The study population was all students of class VII SMPN 1 Jenang (183 students), the sample was VII C and VII D, totaling 62 students. The learning outcome test instrument is in the form of questions totaling 30 questions (25 multiple choice questions and 5 essay questions) and worksheets when making observations. Data collection by tests, observation, documentation. The gain score data were analyzed using the Independent Sample T-Test with the SPSS Version 25 program.The results of the study were the implementation of the outdoor study method in the form of field work on economic activity material on the integrated social studies learning outcomes of junior high school students and there was a significant effect of the outdoor study method in the form of fields. Work on material on economic activities on integrated social studies learning outcomes for junior high school students. This can be seen from the average gain score for the experimental class is higher (34.55) than the control class (21.29). The results of the analysis of the 
Independent Sample T-Test, obtained a p-level of 0.000. The p-level value was less than $0.05(p<0.05)$.

Keywords: Outdoor study, field work, learning outcomes, integrated social studies

\section{PENDAHULUAN}

Pendidikan merupakan investasi suatu bangsa, bekal hidup dan kehidupan manusia dimasa kini dan masa yang akan datang, dan pendidikan memiliki pengaruh terhadap semua aspek kehidupan. Oemar Hamalik mengatakan bahwa pendidikan merupakan proses dalam rangka mempengaruhi siswa agar dapat menyesuaikan diri terhadap lingkungannya dan dengan demikian akan menimbulkan perubahan dalam dirinya yang memungkinkannya untuk berfungsi dalam kehidupan masyarakat. ${ }^{1}$

Proses pengajaran adalah komponen yang paling penting dalam menyelenggarakan pendidikan. Proses mengajar dan membelajarkan tidak hanya terbatas pada aspek-aspek pengetahuan (kognitif) dan keterampilan (psikomotor) saja, melainkan juga meliputi aspek akhlak (afektif) dalam menghayati serta menyadari kehidupan yang penuh dengan masalah, tantangan, hambatan dan persaingan. Maka karena itu, di dalam proses pengajaran, guru harus memahami bahwa setiap siswa mempunyai kemampuan yang berbeda-beda dalam memahami suatu konsep, karena perkembangan anak tergantung sejauh mana anak aktif dan berinteraksi dengan lingkungan. ${ }^{2}$

Guru sebagai komponen pembelajaran menentukan metode yang akan diterapkan di dalam kelas. Metode adalah cara yang teratur untuk mencapai suatu maksud yang inginkan. Jadi, metode mengajar digunakan guru untuk menyampaikan materi agar dapat diserap, dipahami dan dimanfaatkan oleh siswa untuk mewujudkan tujuan pembelajaran yang akan dicapai.

Salah satu metode pembelajaran yang dapat digunakan dalam proses pembelajaran yaitu outdoor study. Metode Outdoor study merupakan pembelajaran yang dilakukan diluar kelas dengan memanfaatkan lingkungan sekitar. Pembelajaran Outdoor study telah diterapkan di berbagai negara, seperti United Kingdom, Amerika Serikat, Australia, Jerman, dan Indonesia. Outdoor study berkembang di United Kingdom mulai tahun 1896 yang dalam

\footnotetext{
${ }^{1}$ Oemar hamalik, Proses Belajar Mengajar, (Jakarta: Bumi Aksara, 2012), 79.

2 Trianto, Model-Model Pembelajaran Inovatif Berorientasi Konstruktivistik, (Jakarta:
} Prestasi Pustaka, 2007), 22. 
Jurnal Ilmiah Ilmu Pengetahuan Sosial Indonesia Nomor 1 Volume 1 Tahun 2021, hal $31-48$

perkembangannya mengadopsi konsep Jenkins dari Jerman. Beberapa fakta menunjukkan bahwa United States of America (USA) merupakan tempat awal perkembangan outdoor study dengan program Outward Bond. Program dari USA selanjutnya diterapkan di Indonesia pada tahun 1990 dengan Outward Bond Indonesia. $^{3}$

Pembelajaran Outdoor Study dapat dilakukan dengan pengamatan kondisi alam (SDA), kondisi sosial, ekonomi, dan budaya masyarakat (SDM) yang ada di sekitar sekolah dimana siswa berada. Dengan demikian, pembelajaran tersebut tidak hanya sekedar mentransfer ilmu antara guru dengan siswa, melainkan membebaskan siswa untuk merasakan, mengamati, menemukan, dan menyimpulkan hasil observasi secara mandiri. Disini, guru berperan sebagai pembimbing, fasilitator, dan motivator yang membantu siswa dalam proses pembelajaran.

Pembelajaran outdoor study merupakan salah satu pembelajaran yang menekankan pada pengalaman seseorang yang diperoleh dari observasi langsung ke lapangan. Pembelajaran outdoor study ini layak diterapkan pada mata pelajaran IPS terpadu khususnya dalam materi kegiatan ekonomi. Hal ini di karenakan dalam materi kegiatan ekonomi terdapat tiga pokok bahasan yaitu produksi, distribusi dan konsumsi dan siswa dengan mudah memahami materi tersebut apabila mereka observasi langsung ke lapangan.

Penerapan pembelajaran Outdoor Study akan mempermudah guru dalam menumbuhkan motivasi belajar siswa. Adanya dorongan mental dalam diri siswa secara otomatis akan memotivasi siswa dalam berperilaku dengan ditunjukkan ketika siswa mengamati, memperhatikan, berdiskusi, memecahkan masalah, dan mengadakan perbandingan antara buku teks dengan kenyataan yang ada di lapangan, sampai pada waktu membuat kesimpulan akhir (evaluasi). ${ }^{4}$

Pembelajaran di luar kelas juga memiliki nilai tambahan sebagaimana diungkapkan oleh Purwati, diantaranya yaitu: 1) dapat meningkatkan keinginan peserta didik untuk mengikuti materi pelajaran guna meningkatkan pengetahuan,

${ }^{3}$ Andri Estining Sejati, dkk, Pengaruh Metode Pembelajaran Outdoor Study terhadap Kemampuan Menulis Karya Ilmiah Geografi SMA, (Jurnal Pendidikan: Teori, Penelitian, dan Pengembangan, Vol. 1 No. 2 bulan Februari, 2016/EISSN: 2502-471X), 80.

${ }^{4}$ Risma Dwi Arisona, Ahmad Farid Utsman, Pengaruh Pembelajaran Outdoor Study terhadap Hasil Belajar IPS Siswa MI, (Jurnal Komunikasi Pendidikan: Vol. 1 (1) 2017/ISSN-P: 2549-1725), 71. 
sikap, dan keterampilan peserta didik, 2) dapat digunakan sebagai media alternatif bagi guru dalam mengembangkan metode mengajar. ${ }^{5}$

Manfaat dari metode pembelajaran outdoor study (Husamah, 2013) antara lain, (1) membuat pikiran menjadi lebih jernih, (2) pembelajaran akan terasa menyenangkan, (3) pembelajaran lebih variatif, (4) belajar lebih rekreatif, (5) belajar menjadi lebih riil, (6) siswa lebih mengenal pada dunia nyata dan luas, (7) tertanam image bahwa dunia sebagai kelas, (8) tempat belajar akan lebih luas (9) kerja otak lebih rileks. ${ }^{6}$

Langkah-langkah yang harus dilakukan dalam menggunakan lingkungan sebagai media dan sumber belajar ada tiga antara lain: 1) langkah persiapan yaitu menentukan tujuan belajar, menentukan objek, menentukan cara belajar, mempersiapkan perizinan, teknis yang diperlukan untuk kegiatan belajar; 2) langkah pelaksanaan yaitu mengerjakan apa yang telah diperintahkan; dan 3) langkah tindak lanjut yaitu kegiatan yang dilakukan di dalam kelas maupun di luar kelas untuk membahas hasil belajar yang telah dilakukan. ${ }^{7}$

Field work atau kerja lapangan adalah metode pembelajaran yang memperkenalkan peserta didik pada dunia kerja tempat mereka dapat mengaplikasikan semua pengetahuan yang mereka peroleh ke dalam dunia kerja. Field work memberikan kesempatan kepada peserta didik untuk menerapkan pengetahuan dan keterampilan yang telah mereka dapatkan sekaligus dapat mengenal dunia kerja yang nantinya akan mereka hadapi secara nyata. Tujuan utama dari metode outdoor study dalam bentuk field work ini adalah memberi kesempatan kepada peserta didik untuk mencapai pengetahuan melalui pengalaman-pengalaman yang tidak mereka dapatkan di dalam kelas.

Kelebihan dari field work ini diantaranya yaitu:

1. Menerapkan prinsip pengajaran modern yang memanfaatkan lingkungan sekitar dalam proses pembelajaran.

${ }^{5}$ Erwin Widiasworo, Strategi dan Metode Mengajar SIswa di Luar Kelas (Outdoor Learning) Secara Aktif, Kreatif, Inspiratif dan Komunikatif, (Yogyakarta: Ar-Ruzz Media, 2016), 91.

${ }^{6}$ Cintami, Mukminan, Efektivitas Outdoor Study untuk meningkatkan hasil belajar Geografi berdasarkan Locus Of Control di Sekolah Menengah Atas Kota Palembang, (Jurnal: Ilmu-ilmu Sosial, Vol. 15 No. 2 Th 2018), 165.

${ }^{7}$ Husamah, Pembelajaran Luar Kelas Outdoor Learning, (Jakarta: Prestasi Pustaka, 2013), 12-15. 
2. Membuat bahan yang dipelajari di sekolah menjadi lebih relevan dan konkrit.

3. Lebih merangsang kreativitas peserta didik dalam belajar. ${ }^{8}$

Setiap hasil dari pemahaman siswa menunjukkan sejauh mana taraf keberhasilan guru dalam proses pembelajaran. Untuk mengetahui hal tersebut,dapat diukur dengan menggunakan 3 ranah, yaitu ranah kognitif, afektif, dan psikomotor atau yang dikenal dengan nama Taksonomi Bloom. Namun demikian, dalam kenyataanya ketiga ranah tersebut dilakukan secara komprehensif, di mana cenderung hanya pada pengukuran ranah afektif saja.Penilaian dilakukan dengan hasil tes siswa setelah menyelesaikan tugas dari guru, belum sampai ke ranah psikomotorik. ${ }^{9}$

Berdasarkan hasil observasi yang telah saya amati pada magang 2 di SMP 1 Jenangan adalah permasalahan siswa yang kurang tertarik dengan mata pelajaran IPS terpadu. Hal tersebut dikarenakan siswa menganggap bahwa mata pelajaran IPS terpadu hanyalah bersifat hafalan dan proses pembelajarannya hanya dengan menggunakan metode ceramah sehingga menjenuhkan. Bahan ajar atau sumber belajar yang digunakan dalam proses pembelajaran hanyalah menggunakan buku paket dan LKS. Siswa diperbolehkan mencari pengetahuan lebih hanya saat berada di rumah karena di sekolah siswa tidak diperbolehkan untuk membawa HP.

Sebenarnya saat proses pembelajaran guru sudah pernah menerapkan pembelajaran di luar kelas dengan memanfaatkan lingkungan sekitar sebagai sumber belajar, tetapi karena keterbatasan dengan waktu maka kegiatan di luar kelas hanya dilakukan pada saat waktu tertentu dan pastinya dengan materi yang sesuai. Proses pembelajaran di luar kelas itu memerlukan waktu yang cukup lama dan harus dipersiapkan dengan matang agar sesuai dengan rencana dan tujuan yang akan dicapai.

Saat praktik mengajar di SMPN 1 Jenangan saya pernah melakukan pembelajaran di luar kelas. Saya mengamati bahwa siswa yang tadinya kurang memperhatikan materi di dalam kelas, tetapi saat di luar kelas mereka

\footnotetext{
${ }^{8}$ Erwin Widiasworo, Strategi dan Metode Mengajar SIswa di Luar Kelas (Outdoor Learning) Secara Aktif, Kreatif, Inspiratif dan Komunikatif, 127-128.

${ }^{9}$ Risma Dwi Arisona, Ahmad Farid Utsman, Pengaruh Pembelajaran Outdoor Study terhadap Hasil Belajar IPS Siswa MI, (Jurnal Komunikasi Pendidikan: Vol. 1 (1) 2017/ISSN-P: 2549-1725), 72.
} 
sangat antusias dan semangat dalam mengerjakan tugas yang telah saya berikan.

Permasalahan yang terjadi diatas dapat berpengaruh terhadap hasil belajar siswa. Hasil belajar adalah hal yang penting karena menunjukkan ketuntasan seseorang dalam pembelajaran dan merupakan ketercapaian dari tujuan pendidikan. Hal tersebut dapat dilihat saat siswa telah melakukan ulangan harian. Banyak siswa yang nilainya kurang dari KKM dan harus melakukan remedial karena untuk memperbaiki nilai mereka yang kurang baik.

Beberapa hasil penelitian terdahulu menunjukkan adanya pengaruh pembelajaran outdoor study terhadap hasil belajar IPS siswa MI. Hal tersebut sudah diterapkan oleh Risma Arisona (2017).

Berdasarkan dari permasalahan di atas maka peneliti tertarik untuk mengadakan penelitian dengan judul "Pengaruh metode pembelajaran outdoor study dalam bentuk field work pada materi kegiatan ekonomi terhadap hasil belajar IPS terpadu siswa SMP”.

\section{METODE PENELITIAN}

Rancangan penelitian ini jenis penelitian yang di gunakan adalah kuantitatif dengan metode quasi experiment. Desain yang di gunakan adalah nonequeivalent control group design yang artinya penelitian untuk menguji hubungan antara variabel metode pembelajaran outdoor study dalam bentuk field work pada materi kegiatan ekonomi (variabel X) dan hasil belajar IPS terpadu siswa SMP (variabel Y).

Penelitian ini populasinya adalah seluruh siswa kelas VII SMPN 1 Jenangan yang berjumlahkan 183 siswa dan sampelnya yaitu kelas VII C dan VII D yang berjumlahkan 62 siswa masing-masing kelas berjumlah 31 siswa yang memiliki kemampuan hampir sama dan homogen. Hal tersebut diperoleh dengan melihat rata-rata nilai UAS semester 1.

Peneliti mengambil sampel dengan teknik purposive sampling yang artinya yaitu teknik penentuan sampel dengan pertimbang tertentu, karena pengambilan sampel dari populasi dilakukan dengan menentukan kelas 
Jurnal Ilmiah Ilmu Pengetahuan Sosial Indonesia Nomor 1 Volume 1 Tahun 2021, hal $31-48$

kontrol dan kelas eksperimen secara setara berdasarkan tingkat kecerdasannya. ${ }^{10}$

Teknik pengumpulan data dalam penelitian ini adalah tes (soal pre-test dan post-test yang berjumlahkan 30 soal yaitu 25 soal pilihan ganda dan 5 soal esai, selain itu ada LKS yang digunakan siswa untuk melakukan obervasi lapangan), dokumentasi dan observasi.

\section{HASIL DAN PEMBAHASAN}

Pengujian hipotesis penelitian ini menggunakan data gain score. Gain score tersebut diperoleh dengan cara mengurangi nilai post-test dengan nilai pre-test. Rata-rata gain score kelas eksperimen sebesar 34.55 dan kelas kontrol sebesar 21.29. Dengan demikian, rata-rata gain score kelas eksperimen lebih tinggi dibanding kelas kontrol dengan selisih 13.26. Berikut tabel 1 perolehan pre-test, post-test dan gain score.

Berikut tabel 1. perolehan pre-test, post-test dan gain score.

\begin{tabular}{|c|c|c|c|}
\hline Kelas & Pre-test & Post-test & Gain score \\
\hline Eksperimen & 51.06 & 85.61 & 34.55 \\
\hline Kontrol & 57.74 & 79.03 & 21.29 \\
\hline
\end{tabular}

\section{Hasil Belajar IPS Terpadu Siswa}

Penelitian ini lakukan pada kelas VII C sebagai kelas eksperimen dengan menggunakan metode pembelajaran outdoor study dalam bentuk field work dan kelas VII D sebagai kelas kontrol dengan metode tanya jawab, diskusi kelompok dan presentasi.

Untuk mengetahui hasil belajar siswa termasuk ke dalam kategori sangat baik, baik, cukup, kurang dan sangat kurang maka terdapat rumus seperti dibawah ini:

$\begin{aligned} \text { Persentase } & =\underset{\text { Jumlah siswa 1 Kelas }}{\text { Frekuensi }} \text { X 100\% }\end{aligned}$

\section{a. Hasil Persentase Pre-Test Kelas Eksperimen}
1) Persentase Kategori baik = 7 X $100 \%$

10 Sugiyono, Penelitain Kuantitatif, (Bandung: Alfabeta, 2018), 138. 
Pengaruh Metode Pembelajaran Outdoor Study dalam Bentuk Field Work

31

$$
=22.58 \%
$$

2) Persentase kategori cukup baik $=19 \quad \mathrm{X} 100 \%$

$=61.30 \%$

3) Persentase Kategori kurang $=5 \quad X 100 \%$

$$
31
$$

$$
=16.12 \%
$$

Tabel 1.2 Persentase Hasil Pre-Test Kelas Eksperimen

\begin{tabular}{|c|c|c|c|}
\hline Inverval & $\begin{array}{c}\text { Frekuensi/ } \\
\text { Jumlah Siswa }\end{array}$ & Kategori & Persentase \\
\hline $81-100$ & - & Sangat baik & - \\
\hline $61-80$ & 7 & Baik & $22.58 \%$ \\
\hline $41-60$ & 19 & Cukup & $61.30 \%$ \\
\hline $21-40$ & 5 & Kurang & $16.12 \%$ \\
\hline $0-20$ & - & Sangat Kurang & - \\
\hline & JUMLAH & $100 \%$ \\
\hline
\end{tabular}

Berdasarkan tabel diatas, dapat diketahui hasil pre-test kelas VII C (kelas eksperimen) yang termasuk dalam kategori baik 7 siswa dengan memperoleh nilai 61-80 dan mendapat persentase $22.58 \%$, berkategori cukup 19 siswa dengan memperoleh nilai 41-60 dan mendapat persentase $61.30 \%$, berkategori kurang 5 siswa dengan memperoleh nilai 21-40 dengan persentase $16.12 \%$. Untuk memperjelas penilaian ini dapat dilihat di lampiran 12 .

\section{b. Hasil Persentase Pre-Test Kelas Kontrol}

1) Persentase kategori baik $=13 \times 100 \%$

\section{1

$$
=41.93 \%
$$

2) Persentase kategori cukup $=15 \quad X 100 \%$ 31

$$
=48.40 \%
$$

3) Persentase kategori kurang $=\quad 3 \quad X 100 \%$

$$
=9.67 \%
$$


Tabel 1.3 Hasil Pre-Test Kelas Kontrol

\begin{tabular}{|c|c|c|c|}
\hline Inverval & $\begin{array}{c}\text { Jumlah } \\
\text { Siswa }\end{array}$ & Kategori & Persentase \\
\hline $81-100$ & - & Sangat baik & - \\
\hline $61-80$ & 13 & Baik & $41.93 \%$ \\
\hline $41-60$ & 15 & Cukup & $48.40 \%$ \\
\hline $21-40$ & 3 & Kurang & $9.67 \%$ \\
\hline $0-20$ & - & Sangat Kurang & - \\
\hline & JUMLAH & $100 \%$ \\
\hline
\end{tabular}

Berdasarkan tabel diatas, dapat diketahui hasil pre-test kelas VII D (kelas kontrol) yang termasuk dalam kategori baik 13 siswa dengan memperoleh nilai 61-80 dan mendapat 41.93\%, berkategori cukup 15 siswa dengan memperoleh nilai 41-60 dan mendapat persentase $48.40 \%$, berkategori kurang 3 siswa dengan memperoleh nilai 21-40 dan mendapat 9.67\%. Untuk memperjelas penilaian ini dapat dilihat di lampiran 13.

\section{c. Hasil Persentase Post-Test Kelas Eksperimen}

1) Persentase kategori sangat baik $=27 \quad \mathrm{X} 100 \%$

\section{1}

$$
=87.10 \%
$$

2) Persentase kategori baik $=\quad 4 \quad \mathrm{X} 100 \%$

$$
31
$$

$=12.90 \%$

Tabel 1.4 Hasil Post- Test Kelas Eksperimen

\begin{tabular}{|c|c|c|c|}
\hline Inverval & Jumlah Siswa & Kategori & Persentase \\
\hline $81-100$ & 27 & Sangat baik & $87.10 \%$ \\
\hline $61-80$ & 4 & Baik & $12.90 \%$ \\
\hline $41-60$ & - & Cukup & - \\
\hline $21-40$ & - & Kurang & - \\
\hline $0-20$ & - & Sangat Kurang & - \\
\hline
\end{tabular}




\begin{tabular}{|c|c|}
\hline JUMLAH & $100 \%$ \\
\hline
\end{tabular}

Berdasarkan pada tabel diatas, dapat diketahui hasil post-test kelas VII C (kelas eksperimen) yang termasuk dalam kategori sangat baik berjumlah 27 siswa dengan memperoleh nilai 81-100 dan dengan persentase $87.10 \%$, yang berkategori baik berjumlah 4 siswa dengan memperoleh nilai 61-80 dan mendapat persentase 12.90\%. Hal ini dapat dlihat pada lampiran 12.

\section{d. Persentase Hasil Post-Test Kelas Kontrol}

1) Pesentase kategori sangat baik $=\underline{8 \quad X 100 \%}$

$$
=25.80 \%
$$

2) Persentase kategori baik $=\frac{23}{31} \times 100 \%$

$$
=74.20 \%
$$

Tabel 1.5 Hasil Post-Test Kelas Kontrol

\begin{tabular}{|c|c|c|c|}
\hline Inverval & Jumlah Siswa & Kategori & Persentase \\
\hline $81-100$ & 8 & Sangat baik & $25.80 \%$ \\
\hline $61-80$ & 23 & Baik & $74.20 \%$ \\
\hline $41-60$ & - & Cukup & - \\
\hline $21-40$ & - & Kurang & - \\
\hline $0-20$ & - & Sangat Kurang & - \\
\hline \multicolumn{3}{|c|}{ JUMLAH } & $100 \%$ \\
\hline
\end{tabular}

Berdasarkan pada tabel diatas, dapat diketahui hasil post-test kelas VII D (kelas kontrol) yang termasuk dalam kategori sangat baik berjumlah 8 siswa dengan memperoleh nilai 81-100 dan mendapat $25.80 \%$, yang berkategori baik berjumlah 23 siswa dengan memperoleh nilai 61-80 dan mendapat $74.20 \%$.

\section{A. Analisis Data (Pengajuan Hipotesis)}

\section{Hasil Observasi}


Hasil observasi dilakukan oleh peneliti dan observer memperoleh beberapa kesimpulan, yaitu:

\section{a. Hasil Observer Aktivitas Peneliti}

Pelaksanaan metode outdoor study dalam bentuk field work pada materi kegiatan ekonomi yang dilakukan oleh peneliti sudah sesuai dengan rencana. Hal ini dapat dibuktikan dipertemuan pertama dengan jumlah skor yaitu 58 dan dipertemuan kedua dengan jumlah 52. Hal ini dapat dilihat dilampiran 15.

Kemudian, untuk memperoleh skor rata-rata, maka jumlah observer dipertemuan pertama + jumlah observer dipertemuan kedua lalu dibagi 2. Data skor aktivitas Peneliti dapat dilihat pada skor dibawah ini:

Tabel 1.6 Hasil Observasi Aktivitas Peneliti

\begin{tabular}{|c|l|l|l|}
\hline $\begin{array}{l}\text { Observer Pertemuan } \\
\text { Pertama }\end{array}$ & $\begin{array}{l}\text { Observer Pertemuan } \\
\text { Kedua }\end{array}$ & $\begin{array}{l}\text { Skor Rata- } \\
\text { rata }\end{array}$ \\
\hline \multicolumn{2}{|c|}{58} & 52 & \multicolumn{2}{|c|}{55} \\
\hline
\end{tabular}

\section{b. Hasil Observasi Aktivitas Siswa}

Aktivitas Siswa dalam merespon terhadap tindakan yang dilakukan oleh peneliti cukup maksimal. Hal ini dapat dilihat dari jumlah skor di pertemuan pertama memperoleh skor 56 dan pertemuan kedua memperoleh skor 50. Hasil ini dapat dilihat di lampiran 15.

Kemudian, untuk memperoleh skor rata-rata, maka jumlah observer dipertemuan pertama + jumlah observer dipertemuan kedua lalu dibagi 2. Data skor aktivitas Peneliti dapat dilihat pada skor dibawah ini:

Tabel 1.7 Hasil Observasi Aktivitas Siswa

\begin{tabular}{|c|l|l|l|}
\hline $\begin{array}{l}\text { Observer Pertemuan } \\
\text { Pertama }\end{array}$ & $\begin{array}{l}\text { Observer Pertemuan } \\
\text { Kedua }\end{array}$ & $\begin{array}{l}\text { Skor Rata- } \\
\text { rata }\end{array}$ \\
\hline 56 & \multicolumn{2}{|c|}{50} & 53 \\
\hline
\end{tabular}

Setelah memperoleh skor rata-rata aktivitas guru dan aktivitas siswa, selanjutnya mencari rata-rata dari hasil skor rata-rata 
aktivitas peneliti+skor rata-rata aktivitas siswa dibagi 2. Adapun hasil aktivitas peneliti 55 dan hasil aktivitas siswa 53 sehingga memperoleh rata-rata 54. Data rata-rata hasil penelitian tersebut dapat dilihat pada tabel di bawah ini:

Tabel 1.8 Hasil Observasi Aktivitas Peneliti dan Aktivitas Siswa

\begin{tabular}{|lc|lc|l|}
\hline $\begin{array}{l}\text { Observer } \\
\text { Pertama }\end{array}$ & Pertemuan & $\begin{array}{l}\text { Observer Pertemuan } \\
\text { Kedua }\end{array}$ & $\begin{array}{l}\text { Skor Rata- } \\
\text { rata }\end{array}$ \\
\hline 55 & \multicolumn{2}{|c|}{53} & 54 \\
\hline
\end{tabular}

Berdasarkan tabel di atas diperoleh rata-rata aktivitas peneliti dan aktivitas siswa dalam pelaksanaan metode pembelajaran outdoor study dalam bentuk field work pada materi kegiatan ekonomi adalah 54 dengan kategori baik. Hal ini mengindikasikan bahwa pelaksanaan metode outdoor study dalam bentuk field work pada materi kegiatan ekonomi dilakukan oleh peneliti sesuai dengan langkah-langkah pelaksaan metode outdoor study dalam bentuk field work pada materi kegiatan ekonomi.

Hasil analisis data gain score dengan menggunakan independen sample t-test (uji-t) pada metode pembelajaran outdoor study dalam bentuk field work pada materi kegiatan ekonomi terhadap hasil belajar IPS terpadu siswa SMP menunjukkan bahwa nilai $(\mathrm{p})=0,000$. Hal ini berarti $0,000<0,05$, maka $\mathrm{H}_{0}$ ditolak dan $\mathrm{H}_{1}$ diterima. Maka, dapat disimpulkan bahwa ada pengaruh yang signifikan metode outdoor study dalam bentuk field work pada materi kegiatan ekonomi terhadap hasil belajar IPS terpadu siswa SMP. Hal tersebut dapat dilihat pada tabel berikut ini.

Tabel 1.9 Hasil Uji-t

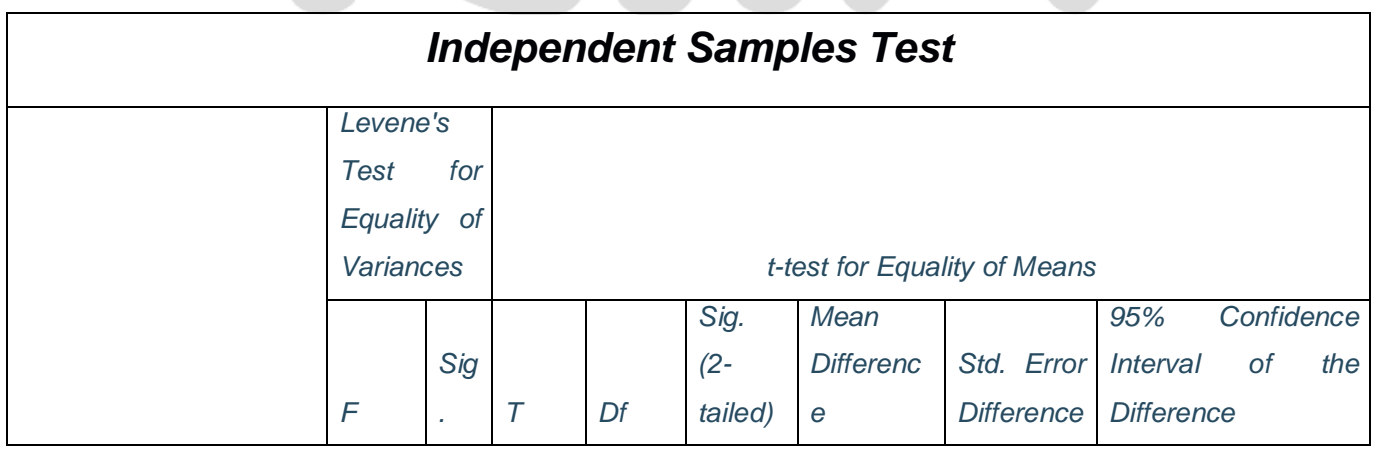


Jurnal Ilmiah Ilmu Pengetahuan Sosial Indonesia Nomor 1 Volume 1 Tahun 2021, hal $31-48$

\begin{tabular}{|c|c|c|c|c|c|c|c|c|c|c|}
\hline & & & & & & & & & Lower & Upper \\
\hline $\begin{array}{l}\text { HASI } \\
\text { L } \\
\text { BELA }\end{array}$ & \begin{tabular}{|l|} 
Equal \\
variances \\
assumed
\end{tabular} & ,000 & $\begin{array}{l}, 99 \\
8\end{array}$ & 5,025 & 60 & ,000 & 13,25806 & 2,63844 & 7,98040 & 18,53573 \\
\hline $\begin{array}{l}\text { JAR } \\
\text { IPS }\end{array}$ & \begin{tabular}{|l|} 
Equal \\
variances \\
not assumed
\end{tabular} & & & 5,025 & $\begin{array}{l}59,96 \\
4\end{array}$ & ,000 & 13,25806 & 2,63844 & 7,98034 & 18,53579 \\
\hline
\end{tabular}

Penelitian Milik Risma Dwi Arisona dengan judul "pengaruh metode pemberian tugas individu berdasarkan observasi lapangan (outdoor study) terhadap kemampuan menulis karya ilmiah dan hasil belajar geografi siswa SMP” menunjukkan bahwa metode pemberian tugas individu berdasarkan observasi lapangan (outdoor study) berpengaruh terhadap kemampuan menulis karya ilmiah dan hasil belajar Geografi siswa SMP. Hal tersebut dapat dilihat dari hasil uji hipotesis dan rata-rata nilai (karya ilmiah dan hasil belajar Geografi) menunjukkan bahwa kelas eksperimen yang melakukan observasi lapangan (outdoor study) lebih tinggi dibandingkan kelas kontrol yang hanya melihat dari tayangan video (indoor study).

Faktor-faktor yang menjadikan hasil belajar siswa kelas eksperimen lebih tinggi dibanding dengan kelas kontrol, yaitu:

Pertama, hasil belajar permanen di Otak (tidak mudah dilupakan). Artinya, siswa tidak akan mudah lupa terhadap semua yang mereka dipelajari di luar kelas. Hal itu dikarenakan dalam kegiatan ini, mereka tidak hanya dituntut untuk menghafal saja, melainkan juga dituntut untuk mencoba, merasakan, mencari, menulis, menelaah, melakukan eksperimentasi, menerapkan, dan melaporkan. ${ }^{11}$

Dengan ungkapan, kegiatan pembelajaran di luar kelas bisa membuat siswa jauh lebih cerdas daripada belajar di dalam kelas. Bahkan, harus diakui, bahwa nilai ujian siswa yang belajar di luar kelas juga lebih tinggi ketimbang nilai ujian mereka yang hanya belajar di dalam kelas. Hal tersebut bisa dibuktikan saat peneliti membagikan lembar soal. Apabila sebelumnya salah satu siswa mendapatkan nilai 66 maka dengan kegiatan belajar dan mengajar di luar kelas nilai tersebut berubah menjadi 84 .

${ }^{11}$ Adelia Vera, Metode Mengajar Anak di Luar Kelas, 39. 
Selain bukti diatas, peneliti juga membagikan lembar Kerja Siswa (LKS) yang dilakukan secara berkelompok di kelas eksperimen dan kelas kontrol. Di kelas eksperimen peneliti memberikan LKS yang dikerjakan saat siswa melakukan obervasi di luar kelas (pasar) dan di kelas kontrol peneliti juga memberikan LKS kepada siswa tetapi dikerjakan di dalam kelas.

Hasil akhir yang didapat dari kedua kelas tersebut berbeda. Hal ini dapat dilihat saat siswa mengumpulkan tugas akhirnya dan pada saat siswa melakukan presentasi, mulai dari pemahaman materi, kemampuan dalam berpendapat, berkontribusi dan bekerja sama. Kelas eksperimen yang melakukan penelitian di lapangan dengan menggunakan outdoor study dalam bentuk field work jauh lebih bagus dibanding dengan kelas kontrol yang mengerjakannya hanya di dalam kelas. Hasil lembar kerja kerja dapat dilihat dilampiran 18.

Kedua, penggunaan media pembelajaran yang kongkrit dan memahami lingkungan yang ada disekitarnya. Saat siswa belajar di luar kelas, mereka dapat menggunakan media pembelajaran yang sesuai dengan materi pelajaran, situasi dan kenyataannya. ${ }^{12}$

Pembelajaran menggunakan metode field work lebih efektif terhadap hasil belajar kognitif, karena siswa dapat mempelajari materi pengelolaan lingkungan melalui obyek nyata dan menghubungkan pengetahuan yang didapatkan di kelas dengan yang mereka temukan di lingkungan. Hasil tersebut selaras dengan pernyataan Purwoko (2007), Sari (2012), Tahe (2013) dan Ratnasari (2014), bahwa keberhasilan pembelajaran menggunakan metode field work terjadi karena siswa mengamati langsung objek yang telah mereka pelajari di kelas sehingga meningkatkan pemahaman siswa terkait materi yang dipelajari.

Pernyataan diatas juga didukung pernyataan Pradyani et al. (2014) dan Ratnasari (2014) bahwa keberhasilan pembelajaran melalui field work juga terjadi karena metode field work memiliki beberapa keunggulan antara lain: siswa memperdalam pembelajaran dengan melihat kenyataan, siswa memperoleh pengalaman langsung dari objek yang dilihatnya, dan siswa dapat melihat, mendengar, meneliti, dan mencoba apa yang dihadapinya. ${ }^{13}$

\footnotetext{
${ }^{12}$ Adelia Vera, Metode Mengajar Anak di Luar Kelas, 32.

${ }^{13}$ Marini, dkk, Efektivitas Metode field Trip di Sungai Kaligarang Semarang Terhadap Hasil Belajar Siswa Materi Pengelolaan Lingkungan, Unnes Journal Of Biology Education, 5 (1) (2016)/ISSN 2252-6579.
} 
Salah satu media yang sesuai dengan materi pelajaran pada saat itu adalah pasar. Seperti yang telah dilakukan di kelas eksperimen, peneliti mengajak siswa untuk melakukan obervasi yang berada di pasar. Di sana mereka diminta untuk melakukan pengamatan, wawancara yang sesuai dengan materi pembelajarannya yaitu kegiatan ekonomi yang di dalamnya terdapat produksi, distribusi dan konsumsi.

Hal yang dilakukan peneliti di atas dikarenakan tidak semua media pembelajaran bisa didapat di dalam kelas. Selain itu, teori yang telah didapat siswa di dalam kelas bisa diaplikasikannya di luar kelas khususnya berada di pasar.

Ketiga, keterampilan studi dan Budaya Kerja. Kegiatan belajar mengajar dengan metode outdoor study dalam bentuk field work ini mampu mendorong siswa untuk menguasai keterampilan studi dan menekuni budaya kerja keras tidak menjadi pemalas. ${ }^{14}$ Hal ini dikarenakan ketika belajar di luar kelas, mereka di tuntut untuk mencari, meneliti, mengamati, dan mengumpulkan berbagai informasi yang berkaitan dengan yang diajarkan yaitu mata pelajaran IPS materi kegiatan ekonomi yang berisikan produksi, ditribusi dan konsumsi.

Hal tersebut harus dilakukan dengan kerja keras, teliti dan tekun, baik secara individual maupun kelompok. Seperti yang telah dilakukan peneliti kepada siswa kelas eksperimen. Siswa diminta untuk melakukan pengamatan, berwawancara dengan orang yang bersangkutan sesuai dengan materi pembelajaran dan mengumpulkan informasi setelah selesai mengerjakan. Hal ini jika hanya dilakukan di dalam kelas tanpa praktek, siswa tidak akan mendapatkan informasi sesuai apa yang diinginkan.

Keempat, mendorong motivasi belajar dan suasana belajar yang menyenangkan. Dorongan motivasi belajar pada siswa dapat muncul karena kegiatan ini menggunakan alam terbuka sebagai sarana pembelajaran. Siswa bisa belajar tanpa batas ruangan yang dapat menyebabkan rasa bosan, kejenuhan, sehingga semakin antusis dalam proses belajar. Ketika rasa jenuh dan bosan muncul, maka otak sangat sulit menerima penjelasan dari guru.

Metode outdoor study dalam bentuk field work ini, guru lebih mudah menciptakan suasana pembelajaran yang menyenangkan bagi siswa. Sebab guru

${ }^{14}$ Adelia Vera, Metode Mengajar Anak di Luar Kelas, 36. 
dapat bereksplorsi dalam menciptakan suasana belajar, seperti bermain, menjelajah, rekreasi, berenang, meneliti, observasi, dll. Cara-cara ini tidak akan mengurangi esensi belajar dan tidak menghilangkaan tujuan belajar yaitu mencerdaskan siswa, bahkan mereka bisa lebih mudah dalam memahami mata pelajaran dengan cara-cara yang tidak monoton.

Hal ini berbeda dengan pembelajaran di kelas, yaitu guru sulit menciptakan suasana pembelajaran yang menyenangkan. Sebab, di dalam kelas, guru tidak memiliki media pembelajaran yang menciptakan suasana belajar menjadi menyenangkan dan pastinya akan membuat siswa menjadi lebih jenuh. ${ }^{15}$

Melihat dari pengamatan peneliti setelah melakukan penelitian kemarin, di kelas kontrol siswa lebih cepat bosan dan kurang aktif dalam proses pembelajaran. Hal tersebut dapat dilihat saat guru sedang menjelaskan ataupun memberikan soal kepada siswa kelas kontrol. Mereka lebih senang berkomunikasi dengan teman sebangku dibanding memperhatikan materi yang telah disampaikan oleh guru. Selain itu, mereka juga kurang aktif saat melakukan diskusi maupun presentasi. Lain halnya dengan kelas eksperimen yang sangat aktif dan juga antusias dalam proses pembelajaran. Karena, mereka senang bisa belajar di luar kelas dan bisa mendapatkan materi ataupun pengetahuan baru yang tidak bisa didapat di dalam kelas.

Hal ini dapat dilihat saat siswa melakukan pembelajaran di pasar, siswa yang sebelumnya di kelas kurang aktif dan kurang bekerja sama, disana mereka bisa bekerja sama dengan baik dan juga aktif dalam melakukan wawanacara. Selain itu, saat presentasi mereka memiliki pengetahuan yang lebih karena, di luar kelas (pasar) mereka melalukan observasi dan berwawanacara dengan orangyang bersangkutan secara langsung.

Kelima, mengasah aktivitas fisik dan kreativitas. Kegiatan belajar mengajar di luar kelas mampu mengasah aktivitas fisik dan kreativitas siswa. Hal itu dikarenakan kegiatan ini menggunakan strategi belajar sambil melakukan atau mempraktikkan sesuai dengan penugasannya. Artinya, ketika siswa belajar di luar kelas, mereka bisa melibatkan semua pancaindra dalam pembelajaran. Tidak hanya mata dan telinga, melainkan juga tangan, kaki, dan aspek motorik lainnya. ${ }^{16}$

\footnotetext{
${ }^{15}$ Adelia Vera, Metode Mengajar Anak di Luar Kelas, 28-30.

${ }^{16}$ Adelia Vera, Metode Mengajar Anak di Luar Kelas, 31-32.
} 
Jurnal Ilmiah Ilmu Pengetahuan Sosial Indonesia Nomor 1 Volume 1 Tahun 2021, hal $31-48$

Dengan ungkapan lain, di luar kelas siswa tidak hanya dituntut memahami pelajaran, tetapi juga mempraktikkan pembelajaran tersebut. Seperti yang telah dilakukan peneliti di kelas eksperimen pada mata pelajaran IPS materi kegiatan ekonomi, siswa diajak pergi ke pasar. Disana mereka bisa mendapatkan pengetahuan yang lebih banyak. Mereka tidak hanya mengetahui teori mengenai produksi, distribusi dan konsumsi saja, tetapi mereka bisa memahami dan melihat bahkan mereka ikut serta dalam bagaimana melakukan produksi? Mengetahui bagaimana cara distributor menyalurkan produksinya agar sampai ke konsumen? Bagaiamana cara menjadi konsumen yang baik?, dll. Jadi mereka tidak hanya mengira-ngira ataupun hanya membayangkan saja, karena di pasar mereka bisa melihat proses produksi, distribusi dan konsumsi secara langsung.

\section{PENUTUP}

Hasil penelitian menunjukkan bahwa metode outdoor study dalam bentuk field work pada materi kegiatan ekonomi berpengaruh terhadap hasil belajar IPS terpadu siswa SMP. Hal ini dapat dibuktikan dari hasil rata-rata gain score kelas eksperimen lebih tinggi dibandingkan kelas kontrol. Hal tersebut disebabkan karena metode pembelajaran outdoor study dalam bentuk field work memberikan kesempatan kepada peserta didik untuk mencari, mengamati hal-hal yang belum pernah mereka dapatkan di dalam kelas dan juga mengkolaborasikan antara materi yang didapat di dalam kelas dengan yang mereka dapatkan di luar kelas sehingga pembelajaran dapat dilaksanakan secara maksimal dan hasil belajar yang tinggi.

\section{DAFTAR PUSTAKA}

Arisona, Risma Dwi, Ahmad Farid Utsman. Pengaruh Pembelajaran Outdoor Study terhadap Hasil Belajar IPS Siswa MI. Jurnal Komunikasi Pendidikan: Vol. 1 (1) 2017/ISSN-P: 2549-1725.

Hamalik Oemar. Proses Belajar Mengajar. Jakarta: Bumi Aksara. 2012.

Husamah. Pembelajaran Luar Kelas Outdoor Learning. Jakarta: Prestasi Pustaka 2013.

Marini, dkk, Efektivitas Metode field Trip di Sungai Kaligarang Semarang Terhadap Hasil Belajar Siswa Materi Pengelolaan Lingkungan, Unnes Journal Of Biology Education, 5 (1) (2016)/ISSN 2252-6579.

Mukminan, Cintami. Efektivitas Outdoor Study untuk meningkatkan hasil belajar Geografi berdasarkan Locus Of Control di Sekolah Menengah Atas Kota Palembang. Jurnal: Ilmu-ilmu Sosial.Vol. 15 No. 2 Th 2018.

Prayadi, I.A.A.M., I Made S., I Made A. Penerapan Metode Field Trip sebagai Upaya Meningkatkan Ketrampilan Menulis Karangan Deskripsi Siswa di 
kelas VII A.3 SMP Negeri 1 Singaraja. E-journal universitas Pendidikan Ganesha, Vol 2 No.1. 2014.

Purwoko, A. Pengembangan Model Investigative Field Work dalam Pembelajaran Biologi untuk Meningkatkan Pemahaman Konsep Ekosistem dan Interaksinya, Minat dan Kerja Ilmiah Siswa. Tesis. Semarang: Universitas Negeri Semarang. 2007.

Ratnasari, D. Pengaruh Pemanfaatan Mangrove Cagar Alam Pulau Dua Melalui Kegiatan Field Trip Terhadap Keterampilan Proses Sains dan Sikap Ilmiah Siswa SMA Pada Konsep Pencemaran Lingkungan. Prosiding Mathematics And Sciences Forum 2014. ISBN 978-602-0960-00-5. 2014.

Sari, I.P. Pemanfaatan Kebun Wisata sebagai Sumber Belajar dengan Menerapkan Pendekatan Jelajah Alam Sekitar (JAS). Unnes.J.biol.educ (2). 2012.

Sejati, Andri Estining, Dkk. Pengaruh Metode Pembelajaran Outdoor Study terhadap Kemampuan Menulis Karya Ilmiah Geografi SMA. Jurnal Pendidikan: Teori, Penelitian, dan Pengembangan. Vol. 1 No. 2 bulan Februari, 2016/EISSN: 2502-471X.

Sugiyono. Penelitain Kuantitatif. Bandung: Alfabeta, 2018.

Trianto. Model-Model Pembelajaran Inovatif Berorientasi Konstruktivistik. Jakarta: Prestasi Pustaka. 2007.

Vera, Adelia. Metode Mengajar Anak di Luar Kelas (Outdoor Study). Yogyakarta: Diva Press 2012.

Widiasworo, Erwin. Strategi dan Metode Mengajar SIswa di Luar Kelas (Outdoor Learning) Secara Aktif, Kreatif, Inspiratif dan Komunikatif. Yogyakarta: Ar-Ruzz Media. 2016. 